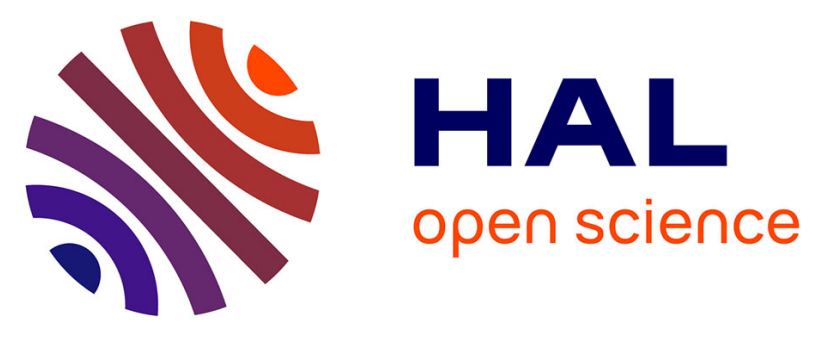

\title{
Thermodynamic insights into the structural basis governing the donor substrate recognition by the human $\beta 1,4$-galactosyltransferase 7
}

Franck Daligault, Sophie Rahuel-Clermont, Sandrine Gulberti, Manh-Thong Cung, Guy Branlant, Patrick Netter, Jacques Magdalou, Virginie Lattard

\section{To cite this version:}

Franck Daligault, Sophie Rahuel-Clermont, Sandrine Gulberti, Manh-Thong Cung, Guy Branlant, et al.. Thermodynamic insights into the structural basis governing the donor substrate recognition by the human $\beta 1,4$-galactosyltransferase 7. Biochemical Journal, 2009, 418 (3), pp.605-614. 10.1042/BJ20081093 . hal-00479032

\section{HAL Id: hal-00479032 https://hal.science/hal-00479032}

Submitted on 30 Apr 2010

HAL is a multi-disciplinary open access archive for the deposit and dissemination of scientific research documents, whether they are published or not. The documents may come from teaching and research institutions in France or abroad, or from public or private research centers.
L'archive ouverte pluridisciplinaire HAL, est destinée au dépôt et à la diffusion de documents scientifiques de niveau recherche, publiés ou non, émanant des établissements d'enseignement et de recherche français ou étrangers, des laboratoires publics ou privés. 


\title{
Thermodynamic insights into the structural basis governing the donor substrate recognition by the human $\beta 1,4$-galactosyltransferase 7
}

\author{
Franck DALIGAULT*, Sophie RAHUEL-CLERMONT ${ }^{\dagger}$, Sandrine GULBERTI*, \\ Manh-Thong CUNG ${ }^{\ddagger}$, Guy BRANLANT ${ }^{\dagger}$, Patrick NETTER ${ }^{*}$, Jacques MAGDALOU* \\ and Virginie LATTARD ${ }^{1^{*}}$
}

*Physiopathologie et Pharmacologie Articulaires, Unité Mixte de Recherche CNRS-UHP 7561, Nancy Université, Faculté de Médecine, BP 184 Vandoeuvre-Les-Nancy, France, †Maturation des ARN et Enzymologie Moléculaire, Unité Mixte de Recherche CNRS-UHP 7567, Nancy Université, Faculté des Sciences et Techniques, BP 239 Vandoeuvre-Les-Nancy, France, ${ }^{\ddagger}$ Laboratoire de Chimie Physique Macromoléculaire, Unité Mixte de Recherche CNRS-INPL 7568, Nancy Université, 1 rue Granville, BP 20451 Nancy, France

Short Title: Substrates recognition by $\beta 1,4-$ GalT7

Human $\beta 1$,4-galactosyltransferase7 ( $\beta 1,4-G a 1 T 7)$ is involved in the biosynthesis of the tetrasaccharide linker protein region ( $\mathrm{GlcA} \beta 1-3 \mathrm{Gal} \beta 1-3 \mathrm{Gal} \beta 1-4 \mathrm{Xy} 1 \beta 1)$ of proteoglycans, by catalysing the transfer of galactose from the uridine 5'-diphosphogalactose, to xylose residue. This reaction is rate-limiting in the glycosaminoglycan biosynthesis. In the present study, we established a large scale production system of the $\beta 1,4-G a 1 T 7$ fused with the maltose-binding protein to study substrate recognition. Calorimetric binding studies showed that the binding of the donor substrate UDP-Gal largely promoted binding of the acceptor substrate. To identify the structural basis governing substrate recognition, we used a fragment-based approach involving the artificial breaking down of donor substrate into smaller fragments and the characterisation of their respective binding to the enzyme by isothermal titration calorimetry. The $\beta$-phosphate, and more moderately the $\alpha$-phosphate, largely contributed to the binding energy. However the uridine moiety was found to be essential for an optimal positioning of the donor substrate within the binding site. Unexpectedly, the contribution of the galactose moiety in substrate recognition was found negligible. Indeed, UDP-Gal, but also various UDP-sugars could bind to $\beta 1,4-$ GalT7. Surprisingly, in contrast to other galactosyltransferases, soluble $\beta 1,4-G a l T 7$ was able to transfer Glc, Xyl, and more moderately GlcA and GlcNAc to acceptor sugars while UDP-Man and UDP-GalNAc were not substrates.

Key words: $\beta 1,4$-galactosyltransferase; substrate recognition; substrate specificity; isothermal titration calorimetry; kinetics; glycosaminoglycan

Abbreviations used: PG, proteoglycan; GAG, glycosaminoglycan; ITC, isothermal titration calorimetry; GalT, galactosyltransferase; MBP, maltose-binding protein; Gal, galactose; Glc, glucose; Man, mannose; GlcA, glucuronic acid; GlcNAc, $N$-acetyl glucosamine; GalNAC, $N$ acetyl galactosamine; Xyl, xylose; pNP-Xyl, 4-Nitrophenyl- $\beta$-D-xylopyranoside; 4MU-Xyl, 4-Methylumbelliferyl- $\beta$-D-xylopyranoside

${ }^{1}$ To whom correspondence should be addressed (E-mail: virginie.lattard@medecine.uhpnancy.fr) 


\section{INTRODUCTION}

Proteoglycans (PGs) represent one of the largest and most complex molecular structures in animals, plants and others. They are composed of polysaccharide glycosaminoglycan (GAG) chains covalently bound to a protein core. The different types of PGs are distinguished by their various core proteins and the composition of their polysaccharide chains (1). Their biological roles are closely related to the presence of these GAG chains, which contain binding sites for various growth factors, cytokines, morphogens, enzymes and other signaling molecules (2-5). These glycoproteins actively partipate in numerous physiological processes at the cell-tissue-organ interface (6). It is becoming clear that they play key roles in cell growth and development (7), angiogenesis (8), viral invasion (9) and anticoagulation (10). Therefore, GAG synthesis has received increasing attention in the recent past. GAG synthesis is initiated by the glycosyltransferase-dependent formation of a common carbohydrate sequence, GlcA $\beta 1-3 \mathrm{Gal} \beta 1-3 \mathrm{Gal} \beta 1-4 \mathrm{Xyl} \beta 1$, bound to specific serine residues in the core protein (11). From this linker tetrasaccharide, the sugar chains are extended by addition of two alternate monosaccharides, an aminosugar and GlcA. The reaction leads to the formation of heparin and heparan-sulfate when the aminosugar is $N$-acetyl-glucosamine and to chondroitin-sulfate and dermatan-sulfate when it is $N$-acetyl-galactosamine. Because of the wide distribution of GAG chains and their common synthetic pathway, defects in their biosynthesis should therefore cause serious abnormalities in a wide variety of tissues and organs. Aberrant and insufficient GAG substitution of PGs was observed in patients affected with the progeroid type of Ehlers Danlos syndrome $(12,13)$. On the contrary, many pathological processes, especially those which are accompanied by an accumulation of extracellular matrix components and connective tissue remodelling, such as fibrotic and sclerotic processes, are characterised by increased PG biosynthesis and deposition (14-16).

Human $\beta 1$,4-galactosyltransferase 7 ( $\beta 1,4-$ GalT7) (EC 2.4 .1 .133 , family GT7 in CAZy database, www.cazy.org) is a Golgi resident type II membrane protein that catalyses the $\mathrm{Mn}^{2+}$-dependent transfer of galactose from UDP-Gal to the nonreducing end of the xylose residue of the common tetrasaccharide linker region of GAGs (17). $\beta 1,4-G a l T 7$ is a member of the $\beta 1,4-$ GalT-related family of enzymes $(18,19)$. These glycosyl transferase family members are classified as "inverting" enzymes because they transfer galactose, from the donor UDP- $\alpha$-D-galactose to an acceptor substrate, generating a $\beta 1 \rightarrow 4$ linkage product (20). $\beta 1,4-G a l T 7$ was shown to be a rate-limiting enzyme in the biosynthesis of GAG chains (21, 22 ) and defects in $\beta 1,4-\mathrm{GalT} 7$, due to mutations (23-25), are involved in severe pathological processes. Therefore, specific inhibitors or activators of this enzyme might represent a good way to modulate GAG biosynthetic pathway. Indeed, $\beta$-D-xyloside analogs are able to prime GAGs, because they serve as substrates for $\beta 1,4-G a l T 7$ (26).

The characterisation of potential ligand-binding sites on a target protein is a prerequisite for successful design of molecules able to inhibit or activate GAGs biosynthesis. In this study, we have used a fragment-based approach that involved the breaking-down of the donor substrate into smaller fragments, to probe for interactions at the substrate-binding site. To assess the ability of substrate fragments to bind to $\beta 1,4-G a 1 T 7$, we used a combination of kinetic, inhibition and isothermal titration calorimetry (ITC) binding studies.

\section{MATERIALS AND METHODS}

\section{Cloning and expression of human $\beta 1,4$-galactosyltransferase 7 in HeLa cells}

The coding sequence corresponding to the human $\beta 1,4-$ GalT7 was amplified by RT-PCR from human brain total RNA using specific primers corresponding to nucleotides 1 to 27 (forward primer) and 961 to 984 (reverse primer) of the reported human $\beta 1,4-G a l T 7$ cDNA (GenBank accession number NM007255). Forward and reverse primers included KpnI and 
EcoRI restriction sites at their extremities, respectively. The reverse primer included a 30 nucleotide sequence coding the amino acid sequence EQKLISEEDL, allowing addition of the myc-tag to the $C$-terminal extremity of the recombinant protein. The purified PCR product amplified with AccuPrime Taq DNA Polymerase (Invitrogen, Cergy Pontoise, France) was then subcloned into pcDNA3.1 (Invitrogen, Cergy Pontoise, France) and sequenced on both strands. The sequence was $100 \%$ identical to that previously reported.

To express membrane $\beta 1,4-G a l T 7$, HeLa cells were cultured in complete Dubelcco's modified Eagle's medium (Gibco, Cergy Pontoise, France) supplemented with glucose (4.5 $\mathrm{g} / \mathrm{L})$, fetal bovine serum $(10 \%)$, glutamine $(1 \mathrm{mM})$ and penicillin-streptomycin $(1 \%)$. The expression plasmid pcDNA- $\beta 1,4-G a 1 T 7 m y c ~(10 \mu \mathrm{g})$ was transfected into HeLa cells on 100 $\mathrm{mm}$ plates using Exgen 500 (Euromedex, Souffelweyersheim, France) according to the manufacturer's recommendations. Two days after transfection, cells were harvested and resuspended in Hepes-sucrose buffer ( $5 \mathrm{mM}$ Hepes, $0.25 \mathrm{M}$ sucrose, $\mathrm{pH}$ 7.4) and briefly sonicated $(1 \times 5 \mathrm{~s})$. Protein concentration of the resulting homogenate was determined by the method of Bradford (27), and $\beta 1,4-G a l T 7 m y c$ protein expression was evaluated by western blot analysis using anti-myc antibodies (Invitrogen, Cergy Pontoise, France) according to the manufacturer's recommendations. The resulting homogenate was used for $\beta 1,4-$ galactosyltransferase activity assay.

\section{Cloning and expression of a soluble form of the $\beta 1,4$-galactosyltransferase 7}

$\beta 1,4-G a l T 7$ was expressed as a fused-protein with the maltose-binding protein (MBP). A truncated form of $\beta 1,4-G a l T 7$, lacking the first $N$-terminal 81 amino acids of the $\beta 1,4-G a l T 7$ was amplified by PCR using specific primers corresponding to nucleotides 244 to 264 (forward primer) and 961 to 984 (reverse primer) including XbaI and HindIII restriction sites, respectively. The PCR product was then subcloned into the pMAL-c2x vector (New England Biolabs, Saint Quentin Yvelines, France) and sequenced on both strands. The sequence was $100 \%$ identical to that previously reported.

To express the soluble MBP-ß1,4-GalT7 fused-protein, Escherichia coli BL21(DE3) cells (Invitrogen, Cergy Pontoise, France) were transformed with pMAL- $\beta 1,4-G a 1 T 7$ plasmid and grown at $37^{\circ} \mathrm{C}$ in Terrific Broth (Sigma, Saint Quentin Fallavier, France) supplemented with ampicillin $(100 \mu \mathrm{g} / \mathrm{mL})$ to an absorbance from 0.6 to 0.8 at $600 \mathrm{~nm}$. Isopropyl $\beta$-thio galactopyranoside (Euromedex, Souffelweyersheim, France) was then added to a final concentration of $0.2 \mathrm{mM}$, and the cells were further incubated overnight at $37^{\circ} \mathrm{C}$. Cells were harvested by centrifugation at $10,000 \mathrm{~g}$ for $10 \mathrm{~min}$ and resuspended in MOPS buffer $(20 \mathrm{mM})$ containing $150 \mathrm{mM} \mathrm{NaCl}$ and $100 \mu \mathrm{g} / \mathrm{mL}$ lysozyme. After incubation for $30 \mathrm{~min}$ at $4^{\circ} \mathrm{C}$, the resuspended cells were disrupted by sonication (i.e., five 30 -s bursts separated by periods of cooling). The solution was centrifuged at $30,000 \mathrm{~g}$ for $30 \mathrm{~min}$ at $4^{\circ} \mathrm{C}$. The resulting supernatant was loaded onto an amylose column (New England Biolabs, Saint Quentin Yvelines, France).

\section{Purification of MBP- $\beta 1,4-G a l T 7$ fused-protein}

All purification procedures were carried out at $4{ }^{\circ} \mathrm{C}$. The resulting supernatant was applied (1 $\mathrm{mL} / \mathrm{min})$ onto an amylose column $(\sim 30 \mathrm{~mL})$ equilibrated with buffer A (20 mM MOPS, $\mathrm{pH}$ 7.0 containing $150 \mathrm{mM} \mathrm{NaCl}$ ). The column was washed with five column-volumes of buffer $A$ and bound proteins were then eluted with maltose $(20 \mathrm{mM})$ in MOPS buffer. Eluted fractions were analysed by SDS-polyacrylamide gel electrophoresis. The fractions containing the MBP- $\beta 1,4-G a l T 7$ fusion proteins were pooled and dialysed extensively against buffer A and then conserved at $-80^{\circ} \mathrm{C}$. The concentration of the purified protein MBP- $\beta 1,4-G a 1 T 7$ was determined by using the 2100 Bioanalyser (Agilent, Massy, France) according to the manufacturer's recommendations. 


\section{Isothermal Titration Calorimetry}

ITC experiments were carried out at $30^{\circ} \mathrm{C}$ in MOPS $(20 \mathrm{mM})$ buffer, $\mathrm{pH} 7.0$ containing $\mathrm{NaCl}$ $(150 \mathrm{mM})$ with or without $\mathrm{MnCl}_{2}(5 \mathrm{mM})$ using a VP-ITC MicroCalorimeter (Micro Cal, Inc.). Ligand solutions were diluted in the final dialysis used for the protein to achieve the expected final concentration (UDP and UDP-Gal, $0.5 \mathrm{mM}$; TDP, UTP and UDP-Glc, $1 \mathrm{mM}$; UDP-GlcA, UDP-Xyl and UDP-Man, $2 \mathrm{mM}$; UDP-GalNAc and UDP-GlcNAc, $5 \mathrm{mM}$; UMP, CDP, 10 mM; pNP-Xyl, 40 mM) (Sigma, Saint Quentin Fallavier, France). Substrate solution was injected into the reaction cell containing the degassed purified protein MBP- $\beta 1,4-G a l T 7$ $(1.4 \mathrm{~mL}, 30 \mu \mathrm{M})$. Thirty 4 to $10 \mu \mathrm{L}$-injections, lasting 8 to $20 \mathrm{~s}$ respectively, were done at 240 $\mathrm{s}$ intervals. During the titration, the enzyme was stirred continuously at $260 \mathrm{rpm}$. Control runs were performed by titrating ligands into buffer. Thermodynamic parameters were obtained from individual experiments performed with three different batches of purified MBP- $\beta 1,4-$ GalT7 and for each batch, determination was performed in duplicate. Thermodynamic parameters $n$ (stoichiometry), $\Delta H$ (enthalpy change) and $K_{\mathrm{a}}$ (association constant) were obtained by nonlinear least-squares fitting of experimental data using the single-site model of the Origin 7.0 software package provided with the instrument. The dissociation constant $\left(K_{\mathrm{d}}\right)$, the free energy of binding $(\Delta G)$ and entropy change $(\Delta S)$ were deduced from the $K_{\mathrm{a}}$ and $\Delta H$ values.

The thermodynamic parameters for donor substrate analogs that have very low affinity were determined by the displacement titration method (28). Titration of the enzyme solution (30 $\mu \mathrm{M})$ was performed with UDP $(0.5 \mathrm{mM})$ in the presence of various substrate analogs (uridine, uracil, ribose, ADP and GDP, 5 to $10 \mathrm{mM}$ ). Thermodynamic parameters $\Delta H$ and $K_{\mathrm{a}}$ for low binding substrate analogs were obtained by nonlinear least-squares fitting of experimental data using the competitive binding model of the Origin 7.0 software package using the thermodynamic parameters obtained for UDP in an independent experiment on the same batch of enzyme.

\section{及1,4-galactosyltransferase activity}

4-Methylumbelliferyl- $\beta$-D-xylo-pyranoside (4MU-Xyl) and 4-Nitrophenyl- $\beta$-D-xylopyranoside (pNP-Xyl) (Sigma, Saint Quentin Fallavier, France) were used as acceptor substrate for the measurement of activity of recombinant human $\beta 1,4-G a l T 7$. Standard reactions were performed in $100 \mathrm{mM}$ cacodylate buffer $(\mathrm{pH} 7.0)$ containing $10 \mathrm{mM} \mathrm{MnCl}_{2}$, $0.6 \mathrm{~g} . \mathrm{L}^{-1}$ of total proteins containing membrane $\beta 1,4-\mathrm{GalT} 7$ or 0.2 to $6 \mu \mathrm{M}$ of purified truncated MBP- $\beta 1,4-G a 1 T 7$, and various concentrations of 4MU-Xyl or pNP-Xyl and UDPGal. After incubation at $37^{\circ} \mathrm{C}$ for $30 \mathrm{~min}$, reaction products were analysed by high performance liquid chromatography (HPLC) on a reverse phase C-18 column $(4.6 \times 150 \mathrm{~mm}$, $4 \mu \mathrm{m}$, Waters, Milford, MA) at a detection wavelength of $320 \mathrm{~nm}$. The mobile phase was composed of $15 \%(\mathrm{v} / \mathrm{v})$ acetonitrile, $0.02 \%(\mathrm{v} / \mathrm{v})$ trifluoroacetic acid in water and used at a flow rate of $1 \mathrm{~mL} / \mathrm{min}$.

Kinetic parameters for 4MU-Xyl or pNP-Xyl and UDP-Gal or other donor substrates were obtained from at least two separate experiments with three different batches of membrane or purified enzymes after the addition of increasing amounts of acceptor or donor substrates ( 0.02 to $10 \mathrm{mM}$ of 4MU-Xyl or pNP-Xyl in the presence of $10 \mathrm{mM}$ of UDP-Gal; 0.025 to 20 $\mathrm{mM}$ of donor substrates in the presence of $10 \mathrm{mM}$ of $4 \mathrm{MU}-\mathrm{Xyl})$ to the standard reaction. The estimation of the kinetic parameters was achieved by the incubation of at least 10 different concentrations of substrate. Incubations were performed in duplicate. Data were fitted by nonlinear regression to the Michaelis-Menten model using the curve fitter program of Sigmaplot $9.0^{\mathrm{Tm}}$. 
In order to evaluate the inhibiting effect of UDP analogs on $\beta 1$,4-galactosyltransferase activity, inhibitors were added to the standard reaction. The estimation of the inhibition constant $\left(K_{\mathrm{i}}\right)$ was achieved by the incubation of at least 8 different concentrations of donor substrate in the presence of three different concentrations of inhibitor. Data were fitted by non-linear regression to the competitive inhibition model using Sigmaplot $9.0^{\mathrm{Tm}}$ software.

\section{Reaction products characterisation}

For reaction products characterisation, $4 \mathrm{mg}$ of $4 \mathrm{MU}-\mathrm{Xyl}$ were glycosylated in the presence of saturating concentration of UDP-Gal, UDP-Glc or UDP-Xyl with 8 to $100 \mathrm{nmol}$ of purified MBP- $\beta 1,4-G a l T 7$, using HPLC as described previously to monitor reaction progress. The reaction products (i.e., 4MU-Xyl-Gal, 4MU-Xyl-Glc and 4MU-Xyl-Xyl) were purifed by HPLC on a reverse phase C-18 column $(10$ x $250 \mathrm{~mm}, 10 \mu \mathrm{m}$, Merck, Darmstadt, Germany) at a detection wavelength of $320 \mathrm{~nm}$. The reaction products and 4MU-Xyl were deuterium exchanged by repeated lyophilisation from $\mathrm{D}_{2} \mathrm{O}$ and then dissolved in $0.5 \mathrm{~mL}$ of $\mathrm{D}_{2} \mathrm{O}(99,8 \%)$ for NMR analysis. Spectra were recorded at $298 \mathrm{~K}$ using a Bruker Avance 300 NMR spectrometer (TOCSY, COSY, 2D-NOESY) and a Bruker DRX 600 spectrometer (onedimensional ${ }^{1} \mathrm{H}$ and $\mathrm{HSQC}$ ). All ${ }^{1} \mathrm{H}$ chemical shifts were referenced to methyl signals of 3(trimethylsilyl)propionic-2,2,3,3-d4 acid sodium salt as an internal standard. ${ }^{13} \mathrm{C}$ chemical shifts were referenced to acetone as an external reference $(30 \mathrm{ppm})$. Water (HOD) residual resonance suppression in the COSY, TOCSY and NOESY experiments was achieved using presaturation during relaxation delay. Data processing was performed using XWIN-NMR software.

\section{RESULTS}

\section{Expression, purification and characterization of human $\beta 1,4-G a l T 7$}

To easily produce and purify pure recombinant human $\beta 1,4-$ GalT7 on a large scale, we expressed in Escherichia coli a soluble form of the enzyme fused with the MBP. Such a soluble form of $\beta 1,4-G a l T 7$ was designed by the deletion of the transmembrane and stem regions, corresponding to the first $81 \mathrm{~N}$-terminal amino acids of the $\beta 1,4-\mathrm{GalT} 7$. The resulting fused MBP- $\beta 1,4-G a l T 7$ protein was 16 -fold purified onto amylose resin (Table 1 ). The relative mobility of the purified MBP- $\beta 1,4-$ GalT7 protein in SDS-PAGE (Figure 1) indicated a homogeneous protein with a molecular weight of approximately $70 \mathrm{kDa}$, consistent with the theorical molecular mass of the truncated $\beta 1,4-G a l T 7$, lacking the first $N$-terminal 81 amino acids and fused with the maltose-binding protein. The purified MBP- $\beta 1,4-G a l T 7$ was found to be active. The formation of the product, using 4MU-Xyl or pNP-Xyl as acceptor substrate, was a linear function of protein concentration. To determine whether the truncation and/or the fusion with the MBP affected the kinetic properties of the MBP- $31,4-G a l T 7$, we determined its apparent affinity constant $K_{\mathrm{m}}$ toward the donor (i.e., UDP-Gal) and the acceptor substrates (i.e., 4MU-Xyl and $\mathrm{pNP}-\mathrm{Xyl}$ ) compared to those of the membrane $\beta 1,4-\mathrm{GalT} 7$ expressed in HeLa cells. $K_{\mathrm{m}}$ values of the MBP- $\beta 1,4-G a l T 7$ toward UDP-Gal and 4MU-Xyl or pNP-Xyl were $0.23 \mathrm{mM}, 0.27 \mathrm{mM}$ and $1.27 \mathrm{mM}$, respectively and were similar to those obtained for the membrane $\beta 1,4-$ GalT7 (Table 2). The $K_{\text {cat }}$ values of the MBP- $\beta 1,4-G a l T 7$ with 4MU-Xyl or pNP-Xyl as acceptor substrate were $68 \mathrm{~min}^{-1}$ and $91 \mathrm{~min}^{-1}$, respectively (Table 2).

\section{Substrate binding to the human $\beta 1,4-G a I T 7$}

To get insight into the mechanism of $\beta 1,4-G a l T 7$, the binding of substrates analogs, UDP and pNP-Xyl, was investigated by ITC. The pNP-Xyl was used as acceptor substrate because of the limited solubility of the 4MU-Xyl when high concentrations are necessary. Prior to this study, we verified the absence of binding of these compounds on the MBP part of the fused protein in the conditions used for titrations with the fused protein. Therefore we expressed and 
purified the MBP protein and analysed the signal detected by ITC after injections of UDP or pNP-Xyl. No calorimetric signal was detected neither with UDP nor with pNP-Xyl.

We first explored the binding of UDP to $\beta 1,4-$ GalT7. Figure $2 \mathrm{~A}$ shows a representative calorimetric profile of UDP binding to the enzyme with and without $\mathrm{Mn}^{2+}$. Binding of UDP to the enzyme was not detected in the absence of $\mathrm{Mn}^{2+}$. On the other hand, when $\mathrm{Mn}^{2+}(5 \mathrm{mM})$ was present, an exothermic binding profile was obtained. From this, the thermodynamic parameters were determined (Figure $2 \mathrm{~A}$ ). A dissociation constant of $9 \mu \mathrm{M}$ was measured. The binding of the donor substrate to MBP- $\beta 1,4-G a l T 7$ was driven by an enthalpy change of $23 \pm$ $5 \mathrm{kcal}^{\mathrm{mol}}{ }^{-1}$, which is partially countered by an unfavourable entropy change (Table 3 ). Moreover, whatever the batch of enzyme, the stoichiometry of UDP binding was between 0.4 to 0.6 . This result prompted us to determine the oligomeric state of the protein. Gel filtration analysis under native conditions showed that MBP- $\beta 1,4-G a l T 7$ eluted with a molecular mass of about $160 \mathrm{kDa}$ (curves not shown). All these data support a dimeric state of the enzyme with only one subunit active within the dimer. Further analyses are needed to explain this unexpected behavior. In that context, it will be necessary to determine the oligomeric state of the enzyme in vivo.

The binding of the acceptor substrate analog (pNP-Xyl) to the enzyme was then analysed with and without UDP (Figure 2B). In both cases, an exothermic signal was detected. However the magnitude of the exothermic signal detected in the presence of UDP was greater than that obtained without UDP, suggesting the requirement of UDP to promote the binding of the acceptor substrate to the enzyme. The signal detected without UDP might be due to nonspecific binding. Only, the signal obtained with UDP reached saturation and generated a significant binding isotherm. The acceptor substrate analog $\mathrm{pNP}-\mathrm{Xyl}$ bound with relatively weak affinities to MBP- $\beta 1,4-G a l T 7$. The $K_{d}$ was higher than the protein concentration, resulting in $c$-values $\left(\mathrm{c}=[\operatorname{Prot}]_{\mathrm{t}} / K_{\mathrm{d}}\right)$ lower than 1 . Under low c-value conditions, both $\Delta G$ and $\Delta H$ can be measured with confidence provided that, at least, $80 \%$ saturation is achieved and that the stoichiometry $n$ is known, as described by Turnbull and Danaras (29). In this experiment, it was possible to reach saturation at sufficiently high ligand concentration. Therefore, we used the stoichiometry value determined independently by the active site titration experiments with UDP under higher $c$-values conditions, for fitting the low c-value titrations. Consequently, the dissociation constant and enthalpy change of binding could be measured and the entropy of binding calculated with reasonable confidence (Figure 2B). The binding of acceptor substrate was driven by an enthalpy change $(-11.8 \mathrm{kcal} / \mathrm{mol})$ with an unfavourable entropy change. pNP-Xyl was found to bind weakly to the enzyme, compared to UDP with an estimated dissociation constant of about 4.6 mM (Figure 2B). This poor binding might be explained by the fact that pNP-Xyl is not the natural ligand and is consistent with the high $K_{\mathrm{m}}$ value determined for pNP-Xyl (Table 2).

\section{Identification of the structural determinants of the donor substrate recognition}

To determine the contributions of individual chemical groups of the donor substrate to the binding affinity and enthalpic and entropic components of the free energy of binding, the thermodynamics of the interaction of MBP- $\beta 1,4-$ GalT7 with UDP analogs were characterised using ITC, by using the stoichiometry value observed for UDP binding (Table 3).

The smallest fragment for which direct binding could be detected was uridine. However, the binding affinity estimated was very weak $\left(K_{\mathrm{d}}>8 \mathrm{mM}\right)$, and a low heat signal prevented an accurate determination of the thermodynamic parameters. In contrast, binding of UMP and UTP was fully characterised by ITC (Table 3). Dissociation constants of 562 and $99 \mu \mathrm{M}$ were obtained, respectively, and were 62- and 11-fold higher than that obtained for UDP binding. No heat released or absorbed was measured with ribose or uracil when these ligands were added in the enzyme solution. Therefore, the binding of ribose or uracil and uridine to the 
enzyme was further demonstrated or confirmed using competitive ITC experiments (Table 3). This indirect approach allows characterisation of weak interaction of the ligand of interest by displacement with a known high-affinity ligand. Titrations of MBP- $\beta 1,4-G a l T 7$ with UDP were performed in the absence or in the presence of uracil, ribose or uridine under otherwise identical conditions. The $K_{\mathrm{d}}$ and $\Delta H$ for UDP obtained from the two titrations were used to estimate the $K_{\mathrm{d}}$ and $\Delta H$ for the weak competitor ligand, by applying the displacement model described by Zhang and Zhang (30), and Sigurskjold (28). As expected, uridine weakly inhibited the binding of UDP to MBP- $\beta 1,4-G a l T 7$. Besides, both uracil and ribose were also able to weakly inhibit the binding of UDP to MBP- $\beta 1,4-G a l T 7$, but with dissociation constants higher than $8 \mathrm{mM}$ (Table 3 ). To further investigate the requirement for the uridine moiety, other nucleotides were also tested (Table 3). TDP and CDP were found to bind weaker to the enzyme, compared to UDP, with estimated dissociation constants 11- and 94fold higher, respectively. No binding was observed for ADP and GDP, even by using competitive ITC experiments (Table 3).

To determine the contributions of the sugar moiety of the donor substrate to the binding, the thermodynamics of the interaction of MBP- $\beta 1,4-G a l T 7$ with various UDP-sugars were characterised using ITC by direct titration (Table 4). First, we compared the binding of UDP and UDP-Gal to MBP- $\beta 1,4-G a l T 7$. The binding of UDP-Gal was also exothermic (Table 4). Dissociation constant of $8.7 \mu \mathrm{M}$ and enthalpy of binding of $-25.0 \mathrm{kcal}^{\mathrm{mol}}{ }^{-1}$ were obtained and both values were similar to those measured when UDP was used as ligand. Because of the low contribution of the galactose moiety on the donor substrate binding, we investigated the enzyme ability to bind other UDP-sugars (Table 4). Direct binding to MBP- $\beta 1,4-G a l T 7$ was observed with all the analogs tested and binding parameters are indicated in Table 4. Except for UDP-Glc, other UDP-sugars were found to bind weakly to the enzyme, compared to UDPGal (Table 4). Furthermore the magnitude of $\Delta H$ for the binding of all these UDP-sugars was less than that for UDP-Gal.

\section{Kinetic studies}

The ITC results prompted us to test the ability of MBP- $\beta 1,4-G a l T 7$ to transfer the sugar part from other naturally occurring UDP-sugars $(2.5 \mathrm{mM})$ to the acceptor substrate. In this section, 4MU-Xyl was used as acceptor substrate because of the better $K_{\mathrm{m}}$ obtained for MBP- $\beta 1,4-$ GalT7 toward this subtrate (i.e., $0.27 \mathrm{mM}$ ) compared to pNP-Xyl (i.e., $1.27 \mathrm{mM}$ ). Surprisingly, MBP- $\beta 1,4-G a l T 7$ catalysed the transfer of Glc, Xyl, GlcA and GlcNAc onto the acceptor substrate (Table 5). In contrast UDP-Man and UDP-GalNAc were not substrates. Kinetic parameters toward UDP-sugars were thus determined and are summarised in Table 5. $K_{\mathrm{m}}$ values of the purified MBP- $\beta 1,4-G a l T 7$ toward UDP-Glc and UDP-Xyl were $0.28 \mathrm{mM}$ and $0.16 \mathrm{mM}$, respectively and were comparable to that obtained for UDP-Gal $(0.23 \mathrm{mM})$. Thus, our results showed that MBP- $\beta 1,4-G a l T 7$ exhibited a markedly higher efficiency toward UDP-Gal compared to UDP-Glc and UDP-Xyl due to the decrease in $k_{\text {cat }}$ values (respectively 58- and 109-fold lower than that obtained with UDP-Gal).

MBP- $\beta 1,4-G a 1 T 7$ was also able to catalyse the transfer of GlcA and GlcNAc onto the acceptor substrate. But the $K_{\mathrm{m}}$ values obtained for both were so high that the determination of $k_{\text {cat }}$ values was not achieved.

To validate the ITC results and to investigate whether the identified ligands were inhibitors, inhibition analyses of the $\beta 1$,4-galactosyltransferase activity using UDP-analogs were carried out and when inhibitory effects were observed, $K_{\mathrm{i}}$ values were determined as indicated in Materials and methods (Table 6). As expected, UDP was the most potent inhibitor and inhibited the $\beta 1$,4-galactosyltransferase activity in a competitive manner with a $K_{\mathrm{i}}$ value of $0.61 \mathrm{mM}$ (Table 6). No significant inhibition of the $\beta 1,4$-galactosyltransferase activity was detected in the presence of donor substrate fragments such as UMP, uridine, uracil or ribose 
(data not shown). On the other hand, inhibitors such as UTP and TDP, which are structurally related to UDP, inhibited significantly the $\beta 1$,4-galactosyltransferase activity in a competitive manner. $K_{\mathrm{i}}$ values were, respectively, $1.65 \mathrm{mM}$ and $1.93 \mathrm{mM}$ (Table 6). The presence of the methyl-group in C5 of thymidine and the addition of one phosphate to UDP had only a negligible effect on the donor substrate binding, as indicated by $K_{\mathrm{i}}$ values. On the contrary, the exocyclic amine group of cytidine limited the inhibition potency and the $K_{\mathrm{i}}$ value was 16 fold higher than that obtained for UDP.

Although MBP- $\beta 1,4-G a l T 7$ was not able to catalyse the transfer of Man or GalNAc from the donor substrates (i.e., respectively, UDP-Man and UDP-GalNAc) onto the acceptor substrate, these donor substrate analogs inhibited the $\beta 1,4$-galactosyltransferase activity, but only at high concentration. However $K_{\mathrm{i}}$ values were too high to be determined (Table 6).

\section{Structural characterisation of the reaction products}

Structural characterisation of the reaction products (i.e., 4MU-Xyl-Gal, 4MU-Xyl-Glc and 4MU-Xyl-Xyl) showed that MBP- $\beta 1,4-G a l T 7$ formed the $\beta 1-4$ linkage between the Gal, Glc or Xyl from the UDP-Gal, UDP-Glc or UDP-Xyl donor substrates, respectively, and the Xyl from the 4MU-Xyl acceptor substrate. Comparison of the three reaction products and the 4MU-Xyl one-dimensional ${ }^{1} \mathrm{H}$ NMR spectra clearly showed an additional anomeric $\left(\mathrm{H}_{1}{ }_{1}\right)$ proton resonance $(4.515 \mathrm{ppm}, 4.581 \mathrm{ppm}$ and $4.501 \mathrm{ppm}$ respectively) with a coupling constant $\left({ }^{3} \mathrm{~J}_{1^{\prime}, 2},=7.9 \mathrm{~Hz},{ }^{3} \mathrm{~J}_{1^{\prime}, 2},=7.9 \mathrm{~Hz}\right.$ and ${ }^{3} \mathrm{~J}_{1^{\prime}, 2},=7.7 \mathrm{~Hz}$ respectively) typical of a sugar residue linked in the $\beta$-configuration (see supplementary data $1 \mathrm{~A} \& 2 \mathrm{~A}$ ). These results for 4MU-Xyl-Gal were in agreement with those obtained in the same conditions by Almeida et al. (17). All ${ }^{1} \mathrm{H}$ and ${ }^{13} \mathrm{C}$ resonances were unambiguously assigned by the TOCSY, COSY and HSQC experiments (Table 7). The linkages in 4MU-Xyl-Glc and 4MU-Xyl-Xyl were established by observation of interglycosidic $\mathrm{H}^{\prime}{ }_{1}-\mathrm{H}_{4}$ correlations in the 2D-NOESY spectra (see supplementary data $1 \mathrm{~B} \& 2 \mathrm{~B}$ ). For these two compounds, correlations between $\mathrm{H}_{1}{ }_{1}$ (anomeric proton of Glc or Xyl linked to 4MU-Xyl) and protons of Xyl from 4MU-Xyl clearly indicated a NOE correlation between $\mathrm{H}^{\prime}{ }_{1}$ and $\mathrm{H}_{4}$, and thus a $\mathrm{C}^{\prime}{ }_{1}-\mathrm{C}_{4}$ linkage. The absence of $\mathrm{H}^{\prime}{ }_{1}-\mathrm{H}_{3}$ and $\mathrm{H}^{\prime}{ }_{1}-\mathrm{H}_{2} \mathrm{NOE}$ correlations excluded $\mathrm{C}^{\prime}{ }_{1}-\mathrm{C}_{3}$ and $\mathrm{C}{ }_{1}-\mathrm{C}_{4}$ linkages. Finally the $\mathrm{H}^{\prime}{ }_{1}-\mathrm{H}_{5 \text { eq }}$ NOE correlation showed a spatial proximity of these two protons but was inconsistent with a $\mathrm{C}_{1}{ }_{1}-\mathrm{C}_{5}$ linkage because of the absence of hydroxyl on this carbon (the endocyclic oxygen linked to $\mathrm{C}_{5}$ is blocked because of the $4 \mathrm{MU}$ aglycon). Consistent with the $\mathrm{C}^{\prime}{ }_{1}-\mathrm{C}_{4}$ linkage, the $4 \mathrm{MU}-\mathrm{Xyl} \mathrm{C}_{4}$ resonance showed a substantial downfield glycosylation induced shift $(\Delta \delta=7.21 \mathrm{ppm}$ and $7.04 \mathrm{ppm}$ for $4 \mathrm{MU}-\mathrm{Xyl}-\mathrm{Glc}$ and $4 \mathrm{MU}-\mathrm{Xyl}-\mathrm{Xyl}$ respectively) that was unique when comparing products to substrate, whereas $C_{3}$ and $C_{5}$ exhibited small upfield shift changes. All of the proton resonances ot the 4MU-Xyl residue exhibited downfield glycosylation-induced shifts: $H_{4}$ was the largest $(\Delta \delta=0.208 \mathrm{ppm}$ and $0.157 \mathrm{ppm}$ for $4 \mathrm{MU}-\mathrm{Xyl}-\mathrm{Glc}$ and $4 \mathrm{MU}-\mathrm{Xyl}-\mathrm{Xyl}$ respectively). These results confirmed the linkage structure of the product as $\beta 1,4$.

\section{DISCUSSION}

PGs play an important role in numerous physiological and pathological processes. Progress in the elucidation of the PG biosynthetic pathway has emphasised the importance of glycosyltransferases. These enzymes are responsible for the biosynthesis of the GAG chains, which are largely involved in the biological roles of PGs. Specific compounds able to modulate the activity of these enzymes might represent attractive compounds able to control the GAG biosynthesis rate. Therefore, structure-function studies of glycosyltransferases appear as a crucial step for future design of potentially valuable drugs. Herein, we focus our work on the identification of the structural determinants involved in the substrate binding by the human recombinant $\beta 1,4-G a l T 7$. This enzyme catalyses the rate-limiting transfer of 
galactose to the xylosylated core protein $(17,31)$ and, indeed, defects of this enzyme result in severe phenotypes (i.e., the progeroid variant of Ehlers-Danlos syndrome) $(23,24)$.

To examine precisely the kinetic and physicochemical properties of $\beta 1,4-G a l T 7$, a convenient expression system allowing the preparation of large amounts of pure recombinant enzyme has been developed. To date, few studies have reported the expression of the $\beta 1,4-G a l T 7(17,32)$. Almeida et al. (17) previously expressed and partially characterised a semi-purified truncated form lacking the first $N$-terminal 63 amino acids of the $\beta 1,4-G a l T 7$. In our previous study (32), we expressed in yeast the $\beta 1,4-G a l T 7$ as a membrane form, but, because no method was available to estimate the concentration of the $\beta 1,4-G a l T 7$ in the membrane fraction, the expressed form was also partially characterised. Herein expression of a soluble $\beta 1,4-G a 1 T 7$ was achieved successfully in Escherichia coli by engineering a fusion protein with MBP and the catalytic domain of $\beta 1,4-G a 1 T 7$. A similar approach has been used by Pedersen et al. (33) to express and purify Exostose Tumor Like 2 (EXTL2). Because $\beta 1,4$-GalT 7 fusion protein is enzymatically active and highly soluble, we decided to characterise the MBP- $\beta 1,4-G a l T 7$ in the current study. This strategy was already used for the studies of other membrane enzymes (34), for which expression and solubility are limited. Consequently, we verified the effect of the MBP fusion on the apparent affinity $\left(K_{\mathrm{m}}\right)$ of the enzyme for UDP-Gal and the acceptor substrates 4MU-Xyl and pNP-Xyl. The $K_{\mathrm{m}}$ of the MBP- $\beta 1,4-G a 1 T 7$ toward UDP-Gal was similar to those determined for the membrane $\beta 1,4-G a l T 7$ expressed in HeLa cells (i.e., 0.31 $\mathrm{mM}$ ) and for the membrane $\beta 1,4-G a l T 7$ previously expressed in yeast (32). The $K_{\mathrm{m}}$ of the MBP- $\beta 1,4-G a l T 7$ toward 4MU-Xyl and pNP-Xyl were also similar to those of the membrane 31,4-GalT7 expressed in HeLa cells.

11,4-GalT7, as other glycosyltransferases, is a two-substrate enzyme leading to the formation of two different products in the presence of divalent cations. Therefore, kinetic analysis of such enzymes is complex. In many studies, a saturated concentration of one of the two substrates has been used to reduce the kinetic analysis of glycosyltransferases to a pseudosingle-substrate reaction. However, the data generated under these circumstances do not reflect the general properties of the enzyme. ITC is a direct method for characterising binding reactions in solution and has been largely employed in binding studies of saccharides with their partners such as lectins $(35,36)$ or proteins $(37)$. In this study, ITC was used to determine whether the binding of the acceptor substrate was affected by the binding of the donor substrate. ITC results showed that the binding of the donor substrate largely promoted the binding of the acceptor substrate analog, which is fully consistent with the mechanism already described for other "inverting" glycosyltransferases (38). However, the acceptor substrate seems able to bind to the enzyme without UDP-Gal, but with a very low affinity $\left(K_{\mathrm{d}}\right.$ $>15 \mathrm{mM}$, Figure 2). Since only pNP-Xyl was used as acceptor substrate in this ITC study, it is not possible to determine whether this phenomenon also occurs with the natural substrate, Xyl-core protein. However, the 3D-structure of the human $\beta 1,4-G a l T 1$ (family GT7 in CAZy database) (39), which is related to the $\beta 1,4-G a l T 7$ (19), indicates that the presence of the UDP-sugar is a prerequisite for acceptor substrate binding, consecutively to a donor substrateinduced conformational change. $\beta 1,4-G a l T 1$ has two flexible loops, one short and one long, highly conserved among $\beta 1,4-G a l T$ family members, which play crucial roles in the catalytic mechanism. Upon binding a metal ion and UDP-Gal, the loops change from an open to a closed conformation, creating the acceptor binding site. This conformational change can be induced by either low concentrations of sugar-nucleotide donor and $\mathrm{Mn}^{2+}$, or high concentrations of acceptor (39). This assumption has to be confirmed in the case of the $\beta 1,4-$ GalT7, but can be postulated by analogy with the $\beta 1,4-G a l T 1$. This would explain why in this study we detected binding of acceptor substrate analog without UDP, because very high concentration of $\mathrm{pNP}-\mathrm{Xyl}$ was necessary to reach saturation. 
Although specific inhibitors of various glycosyltransferases have been primarily designed to mimic the acceptor substrates $(40,41)$, the elucidation of the binding order of subtrates to $\beta 1,4-G a l T 7$ suggests that the design of a potent inhibitor or activator should incorporate structural elements of the donor substrate, as previously proposed for other glycosyltransferases $(42,43)$. Nevertheless structural elements of the acceptor substrate should be also subsequently considered to obtain molecules targeting selectively the $\beta 1,4-$ GalT7. Herein we applied a fragment-based approach to probe for interactions at the donor substrate-binding site by ITC, which is particularly amenable to detect low binding (44). The differences in the enthalpy change of binding between compounds (i.e., the $\Delta \Delta H$ values) (Figure 3) provide insights into the roles of the different structural portions of the donor substrate on its recognition by the $\beta 1,4-$ GalT7. Indeed, $\Delta H$ is derived from the net heats of making and breaking of non-covalent bonds. For the binding of uracil-containing substrates, sequential loss in enthalpy change of binding occurred with the systematic removal of phosphates, with the largest drop upon the removal of $\beta$-phosphate. The increase in the $K_{\mathrm{d}}$ for UMP compared to UDP arises from a major decrease of the enthalpy of binding (with value of $9.3 \mathrm{kcal} / \mathrm{mol}$ ), suggesting that the $\beta$-phosphate might be the key group for donor substrate recognition. Nevertheless, we might suppose also a significant contribution of the $\alpha$ phosphate in the interaction because UMP is the smallest compounds for which significant direct binding or inhibition could be detected. As reported for the human $\beta 1,4-G a l T 1$, the anionic oxygen atoms of the diphosphate group of UDP certainly interact with $\beta 1,4-\mathrm{GalT7}$ through $\mathrm{Mn}^{2+}$ via a DXD sequence highly conseryed in all the $\beta 1,4-G a l T$ family members (45). The major contribution of the $\beta$-phosphate in the recognition, observed in this study, might be due to its interaction with $\beta 1,4-G a l T 7$ through hydrogen bonds, as reported for the bovine $\beta 1,4-G a l T 1$ (family GT7 in CAZy database) (46).

Surprisingly, despite the major contribution of the phosphate groups in the binding of the donor substrate to $\beta 1,4-G a l T 7$, modifications of the uridine moiety change significantly the binding affinity (Figure 3). Binding or inhibition of ADP and GDP could not be detected in this study. Replacing the pyrimidic nucleotides by puric nucleotides might induce a steric hindrance, preventing the binding of the puric analogs. On the other hand, $\beta 1,4-G a l T 7$ has the ability to bind other pyrimidic nucleotides than UDP. Nevertheless enthalpies of binding are largely modified, particularly when CDP is used. The donor pyrimidic analogs, CDP or TDP, might interact with $\beta 1,4$ GalT7 in a completely different way from UDP. Interestingly, the presence of the methyl-group in C5 of TDP does not change the binding affinity as much as the additional exocyclic amine group of cytidine. In the 3D-structure of the bovine $\beta 1,4-$ galT1, the uracil ring is held in position by hydrophobic stacking interaction occurring between a Phe side-chain and an Arg side-chain, but also by hydrogen-bonding contacts between $\mathrm{O} 2$ and $\mathrm{N} 3$ atoms of the uracil ring and the main chain nitrogen and oxygen atoms of Arg189 residue, respectively (46). Since binding of TDP by $\beta 1,4-$ GalT7 is better (8-fold) than that of CDP, same kind of interactions may be supposed for $\beta 1,4-G a l T 7$. Thus, design of inhibitors or activators should take into account the importance of the positioning of the donor analogs in the binding site and this positioning might be different when the uridine portion is modified, as suggested by the fact that UDP is a better inhibitor than TDP, which is better than CDP itself.

Contrary to the uridine moiety, surprisingly, the role of the sugar part seems to be negligible in the binding of the donor substrate. Indeed, when comparison was made between binding of UDP and UDP-Gal by $\beta 1,4-G a l T 7$, no significant difference of $K_{\mathrm{d}}$ or $\Delta H$ was detected. It is likely that the galactose part does not interact or very weakly with $\beta 1,4-G a l T 7$. Glycosyltransferases have been previously reported to be quite specific for the binding of the nucleotide portion while exhibiting some tolerance for different sugars (47). In this way, UDP 
binds nearly as well to bovine $\alpha 1,3-$ GalT (family GT6 in CAZy database) as the natural substrate UDP-Gal (38). Nevertheless, in the 3D-structure of the human $\beta 1,4-G a l T 1$, the Gal $\mathrm{O} 2$ and $\mathrm{O} 3$ hydroxyl groups interact with the side chain carboxylate group of the highly conserved DXD motif and the Gal O4 axial hydroxyl group hydrogen binds with the side chain carboxyl oxygen atoms of the EDDD motif largely conserved between $\beta 1,4-\mathrm{GalT}$ family members. These interactions which are not compatible with the Glc moiety of UDPGlc, because the O4 hydroxyl group in Glc is equatorial, partially govern the strict donor substrate specificity of $\beta 1,4-G a l T 1$ (39). Contrary to $\beta 1,4-G a l T 1, \beta 1,4-G a l T 7$ has the ability to bind other UDP-sugars than UDP-Gal, confirming the low contribution of the galactose moiety in binding and suggesting that the binding donor site has enough space to accommodate larger and more ionic substrates than UDP-Gal. Surprisingly and contrary to what was reported for the other six $\beta 1,4-G a l T s$ (48) which have exclusive specificity for UDP-Gal, $\beta 1,4-G a l T 7$ is also able to transfer these sugar parts, except for Man or GalNAc, generating $\beta 1 \rightarrow 4$ linkage products. The reason why the transfer of Man or GalNAc residue is not possible, while the binding is effective, might be explained by a positioning of these substrates in a non competent mode for efficient catalysis. These findings would certainly be useful for developing specific inhibitors of $\beta 1,4-G a l T 7$.

Thermodynamic analysis of the $\beta 1,4-G a l T 7$ in the present study allowed a better knowledge of the binding contribution of individual fragments of the donor substrate to the $\beta 1,4-\mathrm{GalT} 7$. Such a study provides, based on their ligand efficiency, important insights into potential hot spots at the donor substrate-binding site for future design of drugs able to modulate GAG biosynthesis.

\section{FOOTNOTES}

This work was supported by grants from Agence Nationale pour la Recherche (NT053_42251), by the Région Lorraine, and the "Institut Fédératif de Recherche 111" Bioingénierie. ITC were conducted in the "Service Commun de Biophysicochimie des Interactions Moléculaires" of the University Henri Poincaré, Nancy Université.

We would like to give our thanks to M.H. Piet and A. Kriznik for technical assistance and C. Breton and A. Imberty (CERMAV-CNRS) for helpful discussions. We thank Olivier Fabre and Chrystel Beaufils (UMR CNRS-INPL 7568) for NMR technical support.

\section{REFERENCES}

1 Kjellen, L. and Lindahl, U. (1991) Proteoglycans: structures and interactions. Annu. Rev. Biochem. 60, 443-475

2 Poole, A.R. (1986) Proteoglycans in health and disease: structures and functions. Biochem. J. 236, 1-14

3 Ruoslahti, E. (1989) Proteoglycans in cell regulation J. Biol. Chem. 264, 13369-13372

4 Salmivirta, M., Lidholt, K. and Lindahl, U. (1996) Heparan sulfate: a piece of information. FASEB J. 10, 1270-1279

5 Taipale, J. and Keski-Oja, J. (1997) Growth factors in the extracellular matrix. FASEB J. 11, $51-59$

6 Iozzo, R.V. (1998) Matrix proteoglycans: from molecular design to cellular function. Annu. Rev. Biochem. 67, 609-652

7 Perrimon, N. and Bernfield, M. (2000) Specificities of heparan sulphate proteoglycans in developmental processes. Nature 404, 725-728

8 Sasisekharan, R., Ernst, S. and Venkataraman, G. (1997) On the regulation of fibroblast growth factor activity by heparin-like glycosaminoglycans. Angiogenesis 1, 45-54 
9 Chen, Y., Maguire, T., Hileman, R.E., Fromm, J.R., Esko, J.D., Lindhardt, R.J. and Marks, R.M. (1997) Dengue virus infectivity depends on envelope protein binding to target cell heparan sulfate. Nat. Med. 3, 866-871

10 Petitou, M., Herault, J.P., Bernat, A., Driguez, P.A., Duchaussoy, P., Lormeau, J.C. and Herbert, J.M. (1999) Synthesis of thrombin-inhibiting heparin mimetics without side effects. Nature 398, 417-422

11 Roden, L. (1980) The Biochemistry of Glycoproteins and Proteoglycans, Lennarz, W.G., ed, 269-314, Plenum, NY

12 Kresse, H., Rosthoj, S., Quentin, E., Hollmann, J., Glossl, J., Okada, S. and Tonnesen, T. (1987) Glycosaminoglycan-free small proteoglycan core protein is secreted by fibroblasts from a patient with a syndrome resembling progeroid. Am. J. Hum. Genet. 41, 436-453

13 Quentin, E., Gladen, A., Roden, L. and Kresse, H. (1990) A genetic defect in the biosynthesis of dermatan sulfate proteoglycan: galactosyltransferase I deficiency in fibroblasts from a patient with a progeroid syndrome. Proc. Natl. Acad. Sc.i U S A. 87, 1342-1346

14 Bashey, R.I., Millan, A. and Jimenez, S.A. (1984) Increased biosynthesis of glycosaminoglycans by scleroderma fibroblasts in culture. Arthritis. Rheum. 27, 10401045

15 Gressner, A.M., Krull, N. and Bachem, M.G. (1994) Regulation of proteoglycan expression in fibrotic liver and cultured fat-storing cells. Pathol. Res. Pract. 190, 864882

16 Tajima, S., Nishikawa, T., Hatano, H. and Nagai, Y. (1982) Distribution of glycosaminoglycans in dermal connective tissue from scleroderma patients. J. Dermatol. 9, 405-408

17 Almeida, R., Levery, S.B., Mandel, U., Kresse, H., Schwientek, T., Bennett, E.P. and Clausen, H. (1999) Cloning and expression of a proteoglycan UDP-galactose:betaxylose beta1,4-galactosyltransferase I. A seventh member of the human beta4galactosyltransferase gene family. J. Biol. Chem. 274, 26165-26171

18 Lairson, L.L., Henrissat, B., Davies, G.J., and Withers, S.G. (2008) Glycosyltransferases: structures, functions, and mechanisms. Annu. Rev. Biochem. 77, 521-555.

19 Hennet, T. (2002) The galactosyltransferase family. Cell. Mol. Sci. 59, 1081-1095

20 Sinnott, M.L. (1990) Catalytic mechanism of enzymic glycosyl transfer. Chem. Rev. 90, 1171-1202

21 Nakamura, Y., Haines, N., Chen, J., Okajima, T., Furukawa, K., Urano, T., Stanley, P., Irvine, K.D. and Furukawa, K. (2002) Identification of a Drosophila gene encoding xylosylprotein beta4-galactosyltransferase that is essential for the synthesis of glycosaminoglycans and for morphogenesis. J. Biol. Chem. 277, 46280-46288

22 Takemae, H., Ueda, R., Okubo, R., Nakato, H., Izumi, S., Saigo, K. and Nishihara, S. (2003) Proteoglycan UDP-galactose:beta-xylose beta 1,4-galactosyltransferase I is essential for viability in Drosophila melanogaster. J. Biol. Chem. 278, 15571-15578

23 Okajima, T., Fukumoto, S., Furukawa, K. and Urano, T. (1999) Molecular basis for the progeroid variant of Ehlers-Danlos syndrome. Identification and characterization of two mutations in galactosyltransferase I gene. J. Biol. Chem. 274, 28841-22844

24 Faiyaz-Ul-Haque, M., Zaidi, S.H., Al-Ali, M., Al-Mureikhi, M.S., Kennedy, S., AlThani, G., Tsui, L.C. and Teebi, A.S. (2004) A novel missense mutation in the galactosyltransferase-I (B4GALT7) gene in a family exhibiting facioskeletal anomalies and Ehlers-Danlos syndrome resembling the progeroid type. Am. J. Med. Genet. A. 128, $39-45$ 
25 Seidler, D.G., Faiyaz-Ul-Haque, M., Hansen, U., Yip, G.W., Zaidi, S.H.E., Teebi, A.S., Kiesel, L., and Götte, M. (2006) Defective glycosylation of decorin and biglycan, altered collagen structure, and abnormal phenotype of the skin fibroblasts of an EhlersDanlos syndrome patient carrying the novel Arg270Cys substitution in galactosyltransferase I (beta4GalT-7). J. Mol. Med. 84, 583-594

26 Lugemwa, F.N., Sarkar, A.K. and Esko, J.D. (1996) Unusual beta-D-xylosides that prime glycosaminoglycans in animal cells. J. Biol. Chem. 271, 19159-19165

27 Bradford, M.M. (1976) A rapid and sensitive method for the quantitation of microgram quantities of protein utilizing the principle of protein-dye binding. Anal. Biochem. 72, $248-254$

28 Sigurskjold, B.W. (2000) Exact analysis of competition ligand binding by displacement isothermal titration calorimetry. Anal. Biochem. 277, 260-266

29 Turnbull, W.B. and Danaras, A.H. (2003) On the value of c: can low affinity systems be studied by isothermal titration calorimetry? J. Am. Chem. Soc. 125, 14859-14866

30 Zhang, Y.H. and Zhang Z.Y. (1998) Low-Affinity Binding Determined by Titration Calorimetry Using a High-Affinity Coupling Ligand: A Thermodynamic Study of Ligand Binding to Protein Tyrosine Phosphatase 1B. Anal. Biochem. 261, 139-148

31 Esko, J.D., Weinke, J.L., Taylor, W.H., Ekborg, G., Roden, L., Anantharamaiah, G. and Gawish, A. (1987) Inhibition of chondroitin and heparan sulfate biosynthesis in Chinese hamster ovary cell mutants defective in galactosyltransferase I. J. Biol. Chem. 262, 12189-12195

32 Gulberti, S., Lattard, V., Fondeur, M., Jacquinet, J.C., Mulliert, G., Netter, P., Magdalou, J., Ouzzine, M and Fournel-Gigleux, S. (2005) Phosphorylation and sulfation of oligosaccharide substrates critically influence the activity of human beta1,4galactosyltransferase 7 (GalT-I) and beta1,3-glucuronosyltransferase I (GlcAT-I) involved in the biosynthesis of the glycosaminoglycan-protein linkage region of proteoglycans. J. Biol. Chem. 280, 1417-1425

33 Pedersen, L.C., Dong, J., Taniguchi, F., Kitagawa, H., Krahn, J.M., Pedersen, L.G., Sugahara, K. and Negishi, M. (2003) Crystal structure of an alpha 1,4-Nacetylhexosaminyltransferase (EXTL2), a member of the exostosin gene family involved in heparan sulfate biosynthesis. J. Biol. Chem. 278, 14420-14428

34 Lattard, V., Zhang, J., Tran, Q., Furnes, B., Schlenk, D. and Cashman, J.R. (2003) Two new polymorphisms of the FMO3 gene in Caucasian and African-American populations: comparative genetic and functional studies. Drug Metab. Dispos. 31, 854860

35 Dam, T.K., and Brewer, C.F. (2002) Thermodynamic studies of lectin-carbohydrate interactions by isothermal titration calorimetry. Chem. Rev. 102, 387-429

36 Chervenak, M.C. and Toone, E.J. (1995) Calorimetric Analysis of the Binding of Lectins with Overlapping Carbohydrate-Binding Ligand Specificities. Biochemistry 34, 5685-5695

37 Xie, H., Bolam, D.N., Nagy, T., Szabo, L., Cooper, A., Simpson, P.J., Lakey, J.H., Williamson, M.P. and Gilbert, H.J. (2001) Role of hydrogen bonding in the interaction between a xylan binding module and xylan. Biochemistry 40, 5700-5707

38 Boix, E., Zhang, Y., Swaminathan, G.J., Brew, K. and Acharya, K.R. (2002) Structural basis of ordered binding of donor and acceptor substrates to the retaining glycosyltransferase, alpha-1,3-galactosyltransferase. J. Biol. Chem. 277, 28310-28318

39 Ramakrishnan, B., Boeggeman, E., Ramasamy, V. and Qasba, P.K. (2004) Structure and catalytic cycle of beta-1,4-galactosyltransferase. Curr. Opin. Struct. Biol. 14, 593-600 
40 Lu, P.P., Hindsgaul, O., Compston, C.A. and Palcic, M.M. (1996) New synthetic trisaccharide inhibitors for N-acetylglucosaminyltransferase-V. Bioorg. Med. Chem. 4, 2011-2022

41 Mong, T.K., Lee, L.V., Brown, J.R., Esko, J.D. and Wong, C.H. (2003) Synthesis of Nacetyllactosamine derivatives with variation in the aglycon moiety for the study of inhibition of sialyl Lewis x expression. Chembiochem. 4, 835-840

42 Schafer, A. and Thiem, J. (2000) Synthesis of novel donor mimetics of UDP-Gal, UDPGlcNAc, and UDP-GalNAc as potential transferase inhibitors. J. Org. Chem. 65, 24-29

43 Takaya, K., Nagahori, N., Kurugochi, M., Furuike, T., Miura, N., Monde, K., Lee, Y.C. and Nishimura, S.I. (2005. Rational design, synthesis, and characterization of novel inhibitors for human beta1,4-galactosyltransferase. J. Med. Chem. 48, 6054-6065

44 Ciulli, A., Williams, G., Smith, A.G., Blundell, T.L. and Abell, C. (2006) Probing hot spots at protein-ligand binding sites: a fragment-based approach using biophysical methods. J. Med. Chem. 49, 4992-5000

45 Ramakrishnan, B. and Qasba, P.K. (2001) Crystal structure of lactose synthase reveals a large conformational change in its catalytic component, the beta1,4galactosyltransferase-I. J. Mol. Biol. 310, 205-218

46 Gastinel, L.N., Cambillau, C. and Bourne, Y. (1999) Crystal structures of the bovine beta4galactosyltransferase catalytic domain and its complex with uridine diphosphogalactose. EMBO J. 18, 3546-3557

$47 \mathrm{Hu}, \mathrm{Y}$. and Walker, S. (2002) Remarkable structural similarities between diverse glycosyltransferases. Chem. Biol. 9, 1287-1296

48 Amado, M., Almeida, R., Schwientek, T. and Clausen, H. (1999) Identification and characterization of large galactosyltransferase gene families: galactosyltransferases for all functions. Biochim. Biophys. Acta. 1473, 35-53 


\section{TABLES}

\section{Table 1 Purification of MBP- $\beta 1,4-G a l T 7$}

Purification of MBP- $\beta 1,4-G a l T 7$ was performed onto an amylose resin from a $2 \mathrm{~L}$ culture of recombinant $E$. coli BL21 transformed with the pMAL- $31,4-$ GalT7 plasmid, as described in Materials and Methods.

\begin{tabular}{ccccc}
\hline Purification step & $\begin{array}{c}\text { Total activity } \\
\left(\mu \mathrm{mol}_{\mathrm{min}} \mathrm{m}^{-1}\right)\end{array}$ & $\begin{array}{c}\text { Total protein } \\
(\mathrm{mg})\end{array}$ & $\begin{array}{c}\text { Specific activity } \\
\left(\mathrm{nmol}_{\mathrm{min}} \mathrm{m}^{-1} \cdot \mathrm{mg}^{-1}\right)\end{array}$ & Purification fold \\
\hline Supernatant & 55.1 & 950 & 58 & 1 \\
Amylose Elution & 22.3 & 23 & 970 & 16 \\
\hline
\end{tabular}

Table $2 K_{\mathrm{m}}$ values of the membrane $\beta 1,4-G a l T 7$ expressed in Hela cells (WT-c) and the purified MBP-ß1,4-GalT7 (WT-p) expressed in E. coli toward UDP-Gal and toward 4MU-Xyl or pNP-Xyl.

Standard reactions were performed in $100 \mathrm{mM}$ cacodylate buffer ( $\mathrm{pH} 7.0$ ) containing $10 \mathrm{mM} \mathrm{MnCl}, 0.6 \mathrm{~g} . \mathrm{L}^{-1}$ of total proteins containing membrane $\beta 1,4-G a l T 7$ or $0.2 \mu \mathrm{M}$ of purified MBP- $\beta 1,4-G a l T 7$. Kinetic parameters for 4MU-Xyl and UDP-Gal were obtained after the addition of increasing amounts of acceptor or donor substrates ( 0.02 to $10 \mathrm{mM}$ of $4 \mathrm{MU}-\mathrm{Xyl}$ or pNP-Xyl in the presence of $10 \mathrm{mM}$ of UDP-Gal; 0.025 to $10 \mathrm{mM}$ of donor substrates in the presence of $10 \mathrm{mM}$ of $4 \mathrm{MU}-\mathrm{Xyl})$ to the standard reaction. Each data point represent the mean \pm $2 \mathrm{SD}$ of three individual determinations. nd, not determined.

\begin{tabular}{cccccc}
\hline & UDP-Gal & & \multicolumn{2}{c}{ pMU-Xyl } & \multicolumn{2}{c}{$\mathrm{pNP}-\mathrm{Xyl}$} \\
& $K_{\mathrm{m}}(m M)$ & $K_{\mathrm{m}}(m M)$ & $K_{\mathrm{cat}}\left(\mathrm{min}^{-1}\right)$ & $K_{\mathrm{m}}(m M)$ & $K_{\text {cat }}\left(\mathrm{min}^{-1}\right)$ \\
\hline $\mathrm{WT}-\mathrm{c}$ & $0.31 \pm 0.03$ & $0.16 \pm 0.02$ & $\mathrm{nd}$ & $0.85 \pm 0.07$ & $\mathrm{nd}$ \\
$\mathrm{WT}-\mathrm{p}$ & $0.23 \pm 0.075$ & $0.27 \pm 0.056$ & $68 \pm 8$ & $1.27 \pm 0.15$ & $91 \pm 5$ \\
\hline
\end{tabular}


Table 3 Thermodynamic parameters for the binding of various UDP-analogs to the MBP-ק1,4-GalT7

ITC experiments were carried out at $30^{\circ} \mathrm{C}$ in MOPS $(20 \mathrm{mM})$ buffer, $\mathrm{pH} 7.0$ containing $\mathrm{NaCl}(150 \mathrm{mM})$ with $\mathrm{MnCl}_{2}(5 \mathrm{mM})$ using a VP-ITC MicroCalorimeter (Micro Cal, Inc.). Each data point represent the mean $\pm 2 \mathrm{SD}$ of three individual determinations. nd, not determined by direct titration; - , no binding detected.

\begin{tabular}{|c|c|c|c|c|c|}
\hline & $\begin{array}{c}\Delta G \\
(\mathrm{cal} / \mathrm{mol})\end{array}$ & $\begin{array}{c}\Delta H \\
(\mathrm{kcal} / \mathrm{mol})\end{array}$ & $\begin{array}{c}\Delta S \\
(\mathrm{cal} / \mathrm{mol} / \mathrm{K})\end{array}$ & $\begin{array}{c}-T \Delta S \\
(\mathrm{kcal} / \mathrm{mol})\end{array}$ & $\begin{array}{c}K_{\mathrm{d}} \\
(\mu M)\end{array}$ \\
\hline UDP & $-6880 \pm 160$ & $-22.9 \pm 4.8$ & -54 & 16.07 & 9.0 \\
\hline UTP & $-5460 \pm 100$ & $-20.4 \pm 5.1$ & -50 & 14.91 & 99 \\
\hline UMP & $-4430 \pm 210$ & $-13.6 \pm 0.6$ & -31 & 9.13 & 562 \\
\hline Uridine & nd & nd & nd & nd & $>8000$ \\
\hline Uracil & nd & nd & & nd & $>10000$ \\
\hline Ribose & nd & nd & & nd & $>10000$ \\
\hline TDP & $-5440 \pm 80$ & $-13.5 \pm 3.4$ & $1-$ & 8.10 & 101 \\
\hline CDP & $-4190 \pm 340$ & $-5.4 \pm 0.6$ & & 1.23 & 847 \\
\hline GDP & - & & & - & - \\
\hline $\mathrm{ADP}$ & - & - & - & - & - \\
\hline
\end{tabular}


Table 4 Thermodynamic parameters for the binding of various UDP-sugar to the MBPB1,4-GalT7

ITC experiments were carried out at $30^{\circ} \mathrm{C}$ in MOPS $(20 \mathrm{mM})$ buffer, $\mathrm{pH} 7.0$ containing $\mathrm{NaCl}(150 \mathrm{mM})$ with $\mathrm{MnCl}_{2}(5 \mathrm{mM}$ ) using a VP-ITC MicroCalorimeter (Micro Cal, Inc.) Each data point represent the mean $\pm 2 \mathrm{SD}$ of three individual determinations.

\begin{tabular}{cccccc}
\hline & $\begin{array}{c}\Delta G \\
(\mathrm{cal} / \mathrm{mol})\end{array}$ & $\begin{array}{c}\Delta H \\
(\mathrm{kcal} / \mathrm{mol})\end{array}$ & $\begin{array}{c}\Delta S \\
(\mathrm{cal} / \mathrm{mol} / \mathrm{K})\end{array}$ & $\begin{array}{c}-T \Delta S \\
(\mathrm{kcal} / \mathrm{mol})\end{array}$ & $\begin{array}{c}K_{\mathrm{d}} \\
(\mu \mathrm{M})\end{array}$ \\
\hline UDP & $-6880 \pm 160$ & $-22.9 \pm 4.8$ & -54 & 16.07 & 9.0 \\
UDP-Gal & $-6890 \pm 180$ & $-25.0 \pm 6.2$ & -61 & 18.11 & 8.7 \\
UDP-Glc & $-6500 \pm 280$ & $-11.5 \pm 1.5$ & -17 & 5.02 & 17 \\
UDP-Man & $-5400 \pm 45$ & $-15.3 \pm 0.03$ & -33 & 9.89 & 109 \\
UDP-Xyl & $-5610 \pm 30$ & $-12.1 \pm 0.8$ & -22 & 6.52 & 77 \\
UDP-GlcA & $-5520 \pm 230$ & $-12.6 \pm 3.8$ & -24 & 7.06 & 89 \\
UDP-GalNAc & $-5300 \pm 100$ & $-11.4 \pm 2.1$ & -21 & 6.13 & 129 \\
UDP-GlcNAc & $-5340 \pm 10$ & $-9.43 \pm 0.6$ & -14 & 4.10 & 121 \\
\hline
\end{tabular}

Table 5 Kinetic parameters of the purified $\beta 1,4-G a l T 7$ toward various donor substrate. Standard reactions were performed in $100 \mathrm{mM}$ cacodylate buffer ( $\mathrm{pH}$ 7.0) containing $10 \mathrm{mM} \mathrm{MnCl} 2,0.2$ to 6 $\mu \mathrm{M}$ of purified MBP- $\beta 1,4-$ GalT7. Kinetic parameters were obtained after the addition of increasing amounts of donor substrates $(0.025$ to $20 \mathrm{mM})$ in the presence of $10 \mathrm{mM}$ of $4 \mathrm{MU}-\mathrm{Xyl}$ to the standard reaction. Each data point represent the mean \pm 2 SD of three individual determinations. $n$ is the number of determinations ${ }^{*}$ ND, not detected. ${ }^{*} \mathrm{p}<0.02$ compared to the resuils obtained with UDP-Gal as the donor substrate.

\begin{tabular}{ccccc}
\hline & $\mathrm{n}$ & $\begin{array}{c}K_{\mathrm{m}} \\
(\mathrm{mM})\end{array}$ & $\begin{array}{c}k_{c a t} \\
\left(\mathrm{~min}^{-1}\right)\end{array}$ & $\begin{array}{c}k_{c a t} / K_{m} \\
\left(\mathrm{~min}^{-1} . \mathrm{mM}^{-1}\right)\end{array}$ \\
\hline UDP-Gal & 6 & $0.23 \pm 0.07$ & $68.1 \pm 8.2$ & $2966_{(100 \%)}$ \\
UDP-Glc & 3 & $0.28 \pm 0.02$ & $1.2 \pm 0.2$ & $4.2^{*}{ }_{(1.5 \%)}$ \\
UDP-Man & - & $\mathrm{ND}$ & $\mathrm{ND}$ & $\mathrm{ND}$ \\
UDP-Xyl & 3 & $0.16 \pm 0.02$ & $0.6 \pm 0.1$ & $3.9^{*}{ }_{(1.4 \%)}$ \\
UDP-GlcA & 3 & $>4$ & $>0.2$ & - \\
UDP-GalNAc & - & $\mathrm{ND}$ & $\mathrm{ND}$ & $\mathrm{ND}$ \\
UDP-GlcNAc & 3 & $>10$ & $>0.2$ & - \\
\hline
\end{tabular}


Table $6 K_{\mathrm{i}}$ values for various inhibitors.

The estimation of the $K_{\mathrm{i}}$ was achieved by the incubation in the standart reaction of at least 8 different concentrations of UDP-Gal (from 0.1 to $16 \mathrm{mM}$ ) in the presence of four different concentrations of inhibitor (for UDP, from 0 to $2 \mathrm{mM}$; for UTP and TDP, from 0 to $4 \mathrm{mM}$; for CDP, UDP-Man and UDP-GalNAc, from 0 to 10 $\mathrm{mM})$.

\begin{tabular}{cc}
\hline Inhibitor & $K_{\mathrm{i}}(\mathrm{mM})$ \\
\hline UDP & $0.61 \pm 0.10$ \\
UTP & $1.65 \pm 0.22$ \\
TDP & $1.93 \pm 0.31$ \\
CDP & $>9$ \\
UDP-Man & $>9$ \\
UDP-GalNAc & $>9$ \\
\hline
\end{tabular}


Table $7{ }^{1} \mathrm{H},{ }^{13} \mathrm{C}$ chemical shifts $\delta(\mathrm{ppm})$ and ${ }^{1} \mathrm{H}-{ }^{1} \mathrm{H}$ coupling constants $\mathrm{J}(\mathrm{Hz})$ for $4 \mathrm{MU}$ Xyl acceptor substrate and biosynthetic 4MU-Xyl-Gal, 4MU-Xyl-GIc and 4MU-Xyl-Xyl products in $\mathrm{D}_{2} \mathrm{O}$ at $25^{\circ} \mathrm{C}$.

${ }^{1} \mathrm{H}$ chemical shifts are given in ppm downfield from 3-(trimethylsilyl)propionic-2,2,3,3- $d 4$ acid sodium salt. ${ }^{13} \mathrm{C}$ chemical shifts are referenced to acetone as external reference (30 ppm). N.D. not determined because of signal overlapping.

\begin{tabular}{|c|c|c|c|c|}
\hline & 4MU-Xyl & 4MU-Xyl-Gal & 4MU-Xyl-Glc & 4MU-Xyl-Xyl \\
\hline $\mathrm{H}_{1}^{\prime} / \mathrm{H}_{1}$ & $-/ 5.202$ & $4.515 / 5.212$ & $4.581 / 5.137$ & $4.501 / 5.210$ \\
\hline $\mathrm{H}_{2}{ }_{2} / \mathrm{H}_{2}$ & $-/ 3.619$ & $3.551 / 3.671$ & $3.324^{-1} / 3.653$ & $3.295 / 3.658$ \\
\hline $\mathrm{H}_{3}{ }_{3} / \mathrm{H}_{3}$ & $-/ 3.606$ & $3.671 / 3.766$ & $3.523 / 3.755$ & $3.448 / 3.727$ \\
\hline $\mathrm{H}_{4}{ }_{4} / \mathrm{H}_{4}$ & $-/ 3.746$ & $3.934 / 3.975$ & $3.425 / 3.954$ & $3.647 / 3.903$ \\
\hline $\mathrm{H}_{5 \mathrm{ax}} / \mathrm{H}_{5 \mathrm{ax}}$ & $-/ 3.560$ & $3.731 / 3.645$ & $3.497 / 3.626$ & $3.330 / 3.630$ \\
\hline $\mathrm{H}^{\prime}{ }_{\mathrm{eq}} / \mathrm{H}_{5 \mathrm{eq}}$ & $-/ 4.066$ & $-/ 4.215$ & & $3.998 / 4.203$ \\
\hline $\mathrm{H}^{\prime} 6_{\mathrm{a}}$ & - & 3.825 & 3.951 & - \\
\hline$H^{\prime} 6_{b}$ & - & 3.771 & 3.751 & - \\
\hline${ }^{3} \mathrm{~J}_{1^{\prime}, 2}, /{ }^{3} \mathrm{~J}_{1,2}$ & $-/ 7.0$ & $7.9 / 7.6$ & $7.9 / 7.5$ & $7.7 / 7.7$ \\
\hline${ }^{3} \mathbf{J}_{2}, 3, \cdot /{ }^{3} \mathbf{J}_{2,3}$ & $-/ 9.1$ & $10.6 / 9.1$ & $8.8 / 8.8$ & $9.2 / 9.0$ \\
\hline${ }^{3} \mathrm{~J}_{3^{3}, 4}, /{ }^{3} \mathrm{~J}_{3,4}$ & $-/ 8.8$ & $3.5 / 9.4$ & $9.3 / 9.3$ & $9.2 / 9.0$ \\
\hline${ }^{3} \mathrm{~J}_{4,5}, \mathrm{ax} /{ }^{3} \mathrm{~J}_{4,5 \mathrm{ax}}$ & $-/ 10.6$ & ND / 9.7 & $9.3 / 10.8$ & $9.0 / 9.5$ \\
\hline${ }^{3} \mathrm{~J}_{4,5},{ }^{\prime}$ eq $/{ }^{3} \mathbf{J}_{4,5 \mathrm{eq}}$ & $-/ 5.3$ & $-/ 5.3$ & $-/ 5.1$ & $5.5 / 5.3$ \\
\hline 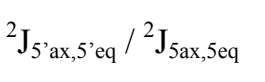 & & $-/-11.7$ & $-/-11.6$ & $-11.7 /-11.7$ \\
\hline${ }^{3} \mathrm{~J}_{5}, 6{ }^{\prime} \mathrm{a}$ & & 8.2 & ND & - \\
\hline${ }^{3} J_{S^{\prime}, 6^{\prime} b}$ & & 3.5 & ND & - \\
\hline${ }^{2} J_{6}{ }^{\prime},{ }^{\prime}{ }^{\prime} b$ & - & -11.7 & ND & - \\
\hline $\mathrm{C}_{1}^{\prime} / \mathrm{C}_{1}$ & (1 & $101.91 / 99.88$ & $101.01 / 99.82$ & $101.66 / 99.85$ \\
\hline $\mathrm{C}_{2}{ }_{2} / \mathrm{C}_{2}$ & -172.35 & $70.63 / 72.40$ & $72.70 / 72.34$ & $72.56 / 72.33$ \\
\hline $\mathrm{C}_{3}{ }_{3} / \mathrm{C}_{3}$ & $-/ 75.20$ & $72.40 / 73.38$ & $75.43 / 73.35$ & $75.39 / 73.24$ \\
\hline $\mathrm{C}_{4}{ }_{4} / \mathrm{C}_{4}$ & $-/ 68.82$ & $68.47 / 75.99$ & $69.42 / 76.03$ & $69.05 / 75.86$ \\
\hline $\mathrm{C}^{\prime}{ }_{5} / \mathrm{C}_{5}$ & $-/ 65.04$ & $75.19 / 62.98$ & 75.78 / 62.92 & $65.03 / 62.93$ \\
\hline $\mathrm{C}_{6}{ }_{6}$ & - & 61.06 & 60.48 & - \\
\hline
\end{tabular}




\section{FIGURE LEGENDS}

Figure 1 Analysis of the purified human MBP-ß1,4-GalT7 fused-protein by SDS-PAGE Human $\beta 1,4-G a l T 7$, lacking the first $N$-terminal 81 amino acids, was expressed in Escherichia coli as a fusedprotein with the MBP, and then, purified onto an amylose column. The supernatant loaded on the amylose column $(10 \mu \mathrm{g}$, lane 1$)$ and the purified MBP- $\beta 1,4-G a l T 7(2 \mu \mathrm{g}$, lane 2$)$ were electrophoresed on polyacrylamide gel $(10 \% \mathrm{w} / \mathrm{v})$ in the presence of SDS and then, stained with Coomassie blue.

Figure 2 Calorimetric profiles of the binding of donor and acceptor substrate analogs to MBP-ß1,4-GalT7

A/ Binding of UDP to MBP- $\beta 1,4-$ GalT7. The reaction cell contained MBP- $\beta 1,4-G a l T 7(1.4 \mathrm{~mL}, 30 \mu \mathrm{M})$ in 20 $\mathrm{mM}$ MOPS buffer containing $150 \mathrm{mM} \mathrm{NaCl}$ in the absence (gray line) or presence (5 $\mathrm{mM}$, black line) of $\mathrm{MnCl}_{2}$. The syringe contained $0.5 \mathrm{mM}$ UDP in the same buffer. Top, raw calorimetric data obtained from the injection of $4 \mu \mathrm{L}$ (11 injections), then $8 \mu \mathrm{L}$ (19 injections) of UDP at 4-min intervals. The bottom plots show the integrated binding isotherm with the experimental points and the corresponding best fit, providing values for thermodynamic parameters calculated in the presence of $\mathrm{MnCl}_{2}$. $\mathrm{B} /$ Binding of $p N P-X y l$ to MBP- $\beta 1,4-$ GalT7. The reaction cell contained MBP- $\beta 1,4-G a l T 7(1.4 \mathrm{~mL}, 30 \mu \mathrm{M})$ in $20 \mathrm{mM}$ MOPS buffer containing $150 \mathrm{mM}$ $\mathrm{NaCl}$ and $5 \mathrm{mM} \mathrm{MnCl}_{2}$ in the absence (gray line) or presence (5 mM, black line) of UDP. The syringe contained $40 \mathrm{mM}$ pNP-Xyl in the same buffer. Top, raw calorimetric data obtained from the injection of $4 \mu \mathrm{L}$ (11 injections), then $10 \mu \mathrm{L}$ (25 injections) of pNP-Xyl at 4-min intervals. The bottom plots show the integrated binding isotherm with the experimental points and the corresponding best fit, providing values for thermodynamic parameters calculated in the presence of UDP.

Figure 3 Free enthalpy change differences $(\Delta \Delta H)$ A / for UDP, UMP and Uracil binding to MBP-ß1,4-GalT7 as compared to UDP-Gal; and B / for TDP and CDP as compared to UDP.

A/ $\Delta \Delta H=\Delta H$ obtained for the binding of UDP, UMP or Uracil - $\Delta H$ obtained for the binding of UDP-Gal. B/ $\Delta \Delta H=\Delta H$ obtained for the binding of TDP or CDP $-\Delta H$ obtained for the binding of UDP. nd, not determined. 
A /

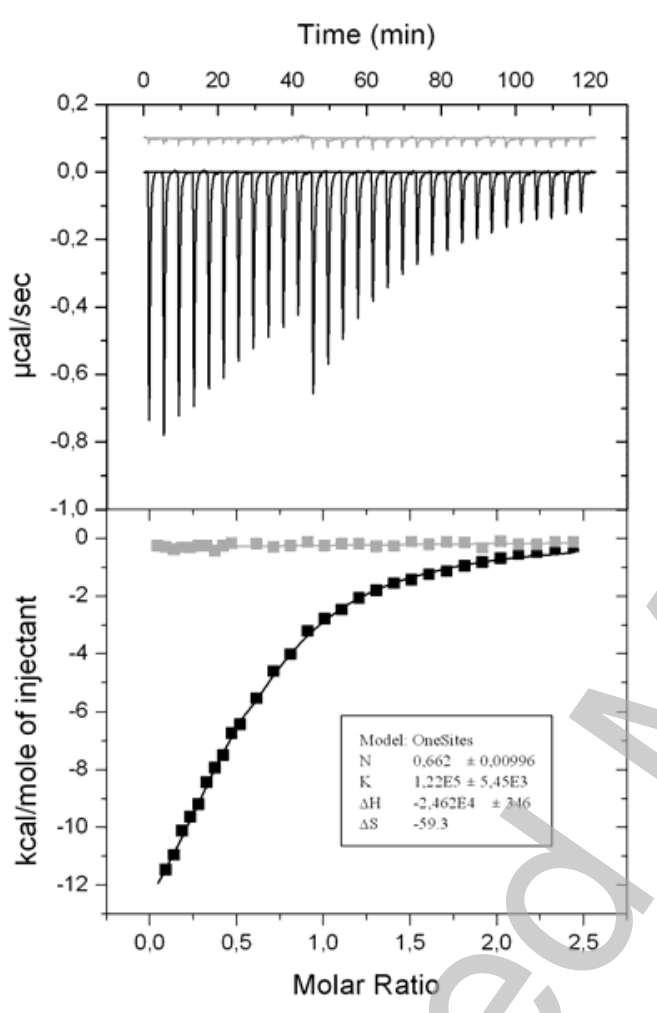

B /

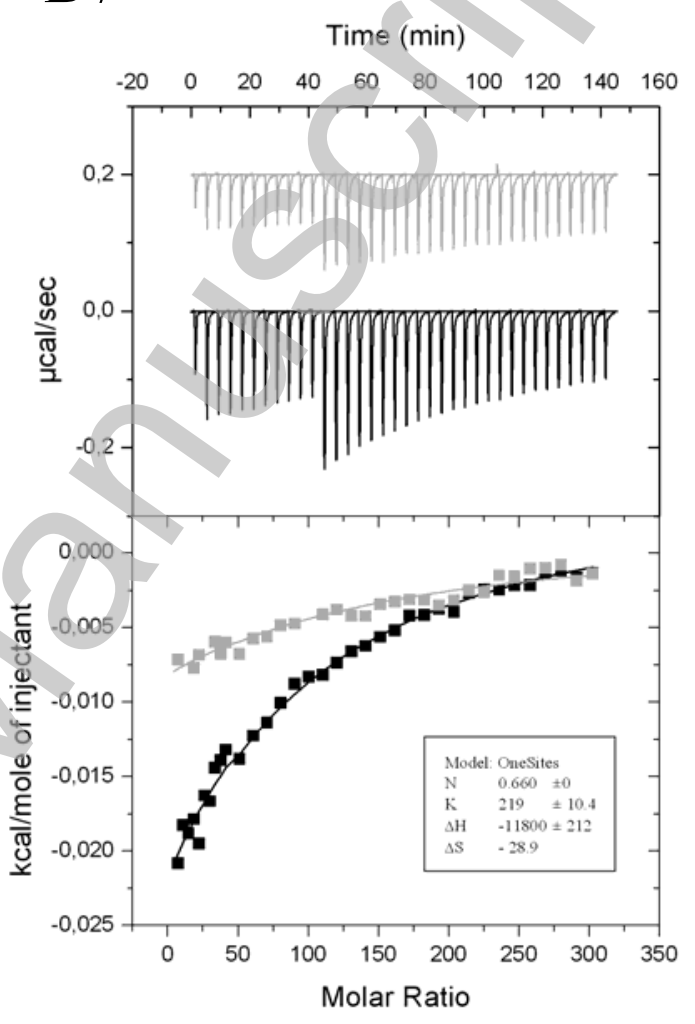

Figure 2 
A /
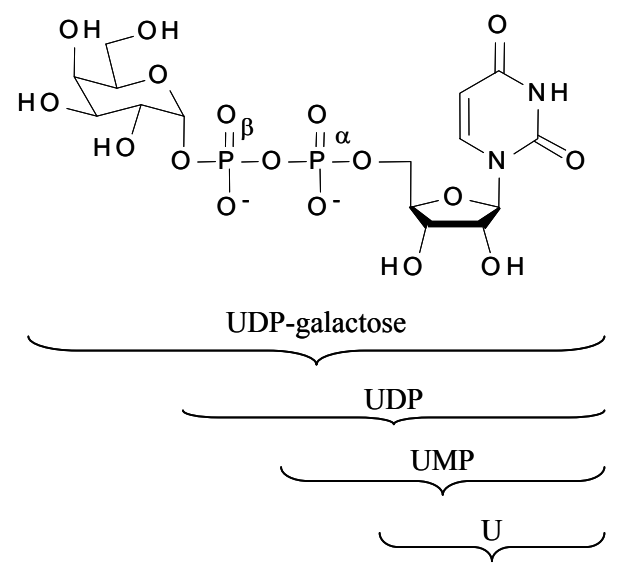

$\mathrm{B} /$

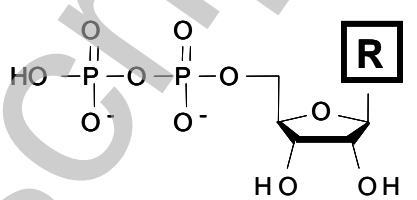

$\Delta \Delta \mathbf{H}$

(kcal/mol)

0

2.1

11.4

nd

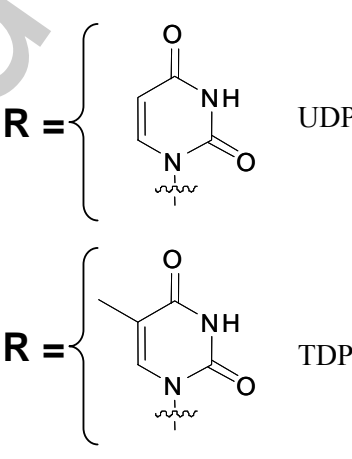

$(\mathrm{kcal} / \mathrm{mol})$

0

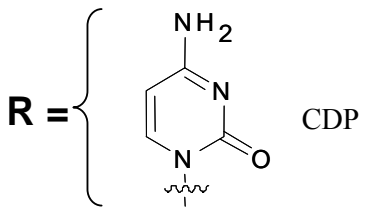

17.5

Figure 3 